January 1985

\title{
Intractable Alcoholism in a Patient with a Levine Shunt
}

Bruce Blumenthal, MS

Thomas Jefferson University Hospital

Howard Field, MD

Thomas Jefferson University Hospital

Ed Gottheil, MD

Thomas Jefferson University Hospital

Linda Guerra, MA

Thomas Jefferson University Hospital

Willis Maddrey, MD

Thomas Jefferson University Hospital

Follow this and additional works at: https://jdc.jefferson.edu/jeffjpsychiatry Soe next page for additional authors

Part of the Psychiatry Commons

Let us know how access to this document benefits you

\section{Recommended Citation}

Blumenthal, MS, Bruce; Field, MD, Howard; Gottheil, MD, Ed; Guerra, MA, Linda; Maddrey, MD, Willis; Serota, MD, Ron; and Shaw, MD, Ellen (1985) "Intractable Alcoholism in a Patient with a Levine Shunt," Jefferson Journal of Psychiatry. Vol. 3 : Iss. 1 , Article 8.

DOI: https://doi.org/10.29046/JJP.003.1.012

Available at: https://jdc.jefferson.edu/jeffjpsychiatry/vol3/iss1/8

This Article is brought to you for free and open access by the Jefferson Digital Commons. The Jefferson Digital Commons is a service of Thomas Jefferson University's Center for Teaching and Learning (CTL). The Commons is a showcase for Jefferson books and journals, peer-reviewed scholarly publications, unique historical collections from the University archives, and teaching tools. The Jefferson Digital Commons allows researchers and interested readers anywhere in the world to learn about and keep up to date with Jefferson scholarship. This article has been accepted for inclusion in Jefferson Journal of Psychiatry by an authorized administrator of the Jefferson Digital Commons. For more information, please contact: JeffersonDigitalCommons@jefferson.edu. 


\section{Intractable Alcoholism in a Patient with a Levine Shunt}

\section{Authors}

Bruce Blumenthal, MS; Howard Field, MD; Ed Gottheil, MD; Linda Guerra, MA; Willis Maddrey, MD; Ron Serota, MD; and Ellen Shaw, MD 


\title{
INTERDISCIPLINARY CASE CONFERENCE: Intractable Alcoholism in a Patient with a Levine Shunt
}

\author{
Bruce Blumenthal, M.S., Howard Field, M.D., Ed Gottheil, M.D., \\ Linda Guerra, M.A., Willis Maddrey, M.D., Ron Serota, M.D., \\ Ellen Shaw, M.D.
}

Ellen Shaw, M.D., Fellow in Hepatology: Mr. J is a forty-six-year-old white male who was initially seen on the medical service in July 1982. At that time he presented with hepatic encephalopathy, jaundice, and ascites. A liver biopsy was performed, confirming the clinical diagnosis of alcoholic hepatitis superimposed on cirrhosis. Following discharge it was difficult to maintain $\mathrm{Mr}$. $\mathbf{J}$ as an outpatient. He did not follow dietary restrictions or take diuretics as prescribed. Additionally he was unable to control his drinking. Finally about a year ago a Levine shunt was implanted in an effort to control his ascites. Subsequently he did well for a period of several months. He was able to abstain from alcohol with a resulting decrease in his ascites and jaundice. Recently he has resumed drinking, with a return of his symptoms. He has missed his last several appointments in the clinic. Control of his medical problems remains problematic unless his alcohol abuse can be better controlled.

Willis C. Maddrey, M.D., Maggey Professor and Chairman of the Department of Medicine: I am grateful for the opportunity to discuss this terrible problem. I know this patient, as many of you do. He is prototypical of a group of patients in whom cirrhosis and all of its complications induced by alcohol has led to a complex situation that is a downward spiral. As Dr. Shaw related, this man developed cirrhosis, the major manifestation of which was ascites. If he would treat himself appropriately, that is to say, be abstinent and take diuretics, in addition to his Levine shunt, then his life expectancy would be reasonable, about ten years. Once you get cirrhosis your life expectancy drops remarkably. But if $\mathrm{Mr}$. J were to take care of himself he would probably be all right for about ten years. Our problem, therefore, is this patient's persistent addiction to alcohol. As you know, when this patient dried out, he took a look at his life and decided it was better to be an alcoholic. That's our problem.

What I would like to talk about is the part I work with the most: the physical consequences of alcohol abuse. You are all aware of the statistics, but they are worth reviewing. About one in ten chronic alcoholics will develop cirrhosis. A chronic alcoholic to a hepatologist is someone who drinks more than sixteen ounces of eighty-six proof whiskey or its equivalent a day. I'm not using a social definition. There are people who are impaired at less than that and others who are not at much more than that. In fact, I have a number of patients with minimal liver abnormalities in whom I'm relatively certain that they're telling me the truth when they tell me they 
drink somewhere between twenty-four and thirty-six ounces of eighty-proof whiskey a day and are still able to function at a high level. In general, however, we think that someone is at risk when they drink more than sixteen ounces of eighty-six proof whiskey a day, the equivalent of sixteen bottles of beer or three bottles of wine. A remarkable number of people drink that much in this country, as many as one in five.

The manifestations of cirrhosis are several. First, there is weakness and fatigue. Those are the main manifestations. Secondly, there are problems that are related to liver damage; these are either bleeding or ascites. Later in the course occurs the development of mental status changes, what we call hepatic encephalopathy. Here is where the interface between psychiatry and hepatology occurs. One of the complications of chronic alcoholism is clearly a loss of brain cells. If you measure the brains of chronic alcoholics, the thickness of their cortexes is less. If you do sections, they've lost cerebral cells. Now as you all know, if you lose cells from your cerebral cortex, the main thing you lose is your ability to store and process recent information. Most of our patients can breathe and their hearts still beat, but they can't think.

Additionally, we are all aware of the short term memory defects of the detoxifying alcoholic. I did a study on this a few years ago on a group of cirrhotic patients who were admitted for detoxification. Early in their course I talked to these patients and said the usual things a doctor says, "You know, you shouldn't drink. You know drinking caused your problems." The patients would say, "Sure doc." They'd all heard it before. I don't think I've ever been the first person to tell an alcoholic to stop drinking. It's very difficult to find the first person who told an alcoholic he shouldn't be drinking. Anyway, I gave these patients a little test. I said, "Look, if you can remember the following things for two weeks I'll give you five dollars." I took a five dollar bill out of my pocket and showed it to them. To many of these patients five dollars would make a difference, so there was some incentive. The facts I gave them were fairly simple, for example, the name of a senator from an adjacent state. Most people don't know, unless they're up in society, the names of the senators from adjacent states, so that's a nice thing to ask. Then I asked them to remember my telephone number. It's not too difficult to remember a seven digit number. I gave them plenty of time. I said they couldn't write it down, but they could ask me plenty of questions so they were sure they had it right. What do you think happened?

Ten days later eighty per cent of them could not remember the conversation. These were people in their third day of detox, so they were no longer visibly drunk. They were awake and alert, not in delirium tremens. The point is most of them didn't even remember the conversation. So I took another group. I went in at a week out. You'd think that at a week out it'd work, but do you know that only fifty per cent of them remembered the conversation a week later.

What this tells us is that you might as well not spend your time talking to these folks in any meaningful way for the first week of detoxification because they're not going to remember the conversation. That doesn't mean that you don't say to them, "Drinking got you here and we're going to help you." That kind of reassurance, "I'm here to help you," is very good. It establishes a trusting doctor-patient relationship. But 
you might as well be talking to a puppy at this time because you're not going to be able to make cerebral connections. I think this is a very important point when we look at the interface between psychiatry and medicine.

No one knows why alcoholics lose brain cells. For a long time it was thought that this was related to vitamin deficiencies. But now we know it's not. Even vitamin-replete patients, and many alcoholics, particularly upper and middle class patients, know about the vitamin deficiency theory and are on megavitamins while developing liver disease because they think it's protective. Many times in the last twenty years there have been reasons for them to believe that. There was a report in the mid-fifties that suggested if you took niacin with beer, that beer wouldn't harm you. So many beer drinkers took niacin with their beer. One beer company was even considering adding niacin to their beer. It turns out that alcohol inactivates the metabolism of niacin, so it would have made no difference. Other people have done the same thing with pyrodoxine. There are all kinds of megavitamins that have been proffered to be protective against alcoholic damage.

Our current theory, based on evidence from animals, is that alcohol is directly toxic to neuronal cells. Whatever the reason, we are faced with a middle-aged man who has been a heavy drinker for more than twenty years. Now at age forty-six when we have reason to suspect that he's lost a good deal of his brain capacity (or maybe he didn't have it to start with — one can never be sure), we are faced with convincing this patient that he shouldn't drink. One of the best evidences of this patient's decreased cerebral functioning is his inability to understand the simple idea that he has ascites, that he doesn't like ascites, and if he didn't eat salt and drink, that his ascites would go away. But he didn't have enough of what it took, either cerebrally or emotionally, obviously it's a combination, to stop drinking. What we've got, then, is the old butting-our-head-against-the-wall syndrome. I'm not sure there's any way we can talk this man into taking proper care of himself.

My experience with many patients with alcoholic liver disease is that about twenty-five per cent of my private patients from stable homes can stop drinking. Every one that I've had stop in Mr. J's situation has stopped as a result of joining a program. I have never yet seen a real alcoholic with liver disease stop on his own. Not one. Now I know there are some. I've heard of it, but I've never seen one. It's a little bit like a unicorn: I believe they exist, but I don't know anyone who's seen one. So I think you need some formal program. Now whether this program is self help through AA, the ultimate in group dynamics, or through a psychiatric program run through a hospital is beyond my control, although I do try to get my patients to go to hospitals. I think they get better taken care of there because of the dedication of the staff and the subsequent support groups.

Now in a gentleman like Mr. $\mathbf{J}$ what can we do? We do everything we can. We give him megavitamins because we want to make sure there are no associated vitamin deficiencies that might occur. The Levine shunt is in place. It's probably blocked by now. They tend not to last very long, a year or two at the most. There is no evidence to suggest that giving this patient Antabuse ${ }^{\circledast}$ may be useful. To give him Antabuse ${ }^{\circledast}$ and expect that he would even take it is naive. This is a man who has been through a major 
surgical procedure for ascites which he was convinced was a consequence of his drinking and that didn't stop him. I've seen people go back to drinking after varicele hemorrhages in which they've had Blakemore tubes down their nose for five days in the intensive care unit. I used to say, "How in the world can a human being go through that?", until I realized that they don't remember. Even though they're awake, they don't remember. If there's one message I can give you folks at the interface, it's that you should be kind to them during the first week, but don't blow your big guns during the first week to ten days in terms of outlining a program for them: there's just no way they'll remember it. Just for fun, try that little test I gave you.

I think that psychiatrists fall into two groups with regard to alcoholics: they either like them or they don't. I think it's very important that each of us learn our own feelings toward alcoholics. I don't like alcoholics, but I don't dislike them either. I'm a liver doctor, so I'm able to remain somewhat neutral. I can't imagine a much more frustrating life than being a psychiatrist who only took care of alcoholics because you've got so many people who are constantly failing. I have heard of programs with success rates of up to fifty per cent, but I think part of that is due to the motivation of people who attend those programs. Succeeders find programs that succeed.

Howard Field, M.D., Director of Consultation and Liaison Psychiatry: Is there a watershed in the development of cirrhosis, any way to determine by laboratory methods when the patient has crossed that point?

Dr. Maddrey: No, not really. Two-thirds of cirrhotics present silently. The patient is already cirrhotic before clinical manifestations appear. Remember, only one in ten alcoholics develop cirrhosis. That's applicable in a social sense as well. Of all alcoholics who lose their jobs, only about one in ten will develop cirrhosis. They may have other complications of drinking, of course. Even the usual biochemical tests will not tell. The best way to pick up early alcohol-related disease is the physical examination, by detecting an enlarged liver. Most patients with alcohol induced liver injury will have an enlarged liver. About one in four will have a tender liver. But that means that three of four will not have a tender liver. So that's a soft sign, too.

John Matt Dorn, M.D., Resident in Psychiatry: Dr. Maddrey, could you comment on the use of psychotropics in cirrhotics?

Dr. Maddrey: All right. The rules are nice and simple. For ninety-nine per cent of everything we use assume a doubling of the half-life of the drug. The hypnotic we used to utilize was chloral hydrate, the half-life of which is doubled in cirrhotics. Today's chloral hydrate is Dalmane ${ }^{\circledR}$, the half-life of which is 2.5 times normal in cirrhotics. What that really means is that is you give a patient fifteen or thirty milligrams of Dalmane ${ }^{\circledR}$ at night at say ten o'clock, they have a soporific effect for twelve instead of the normal six hours. Moreover, they have a partial soporific effect for four hours after that, so that when they're supposed to be awake, they're groggy instead. As a result, people are likely to push them around and call them old stumble drunks.

Another manifestation that is common to early hepatic encephalopathy is day-night reversal. Now put yourself in the place of the general physician if the wife of a fifty-year-old laboror brings him to you and says: "Doctor, I'm worried about my kids. He's about to lose his job. I just know he'd be all right if he could get some rest. $\mathrm{He}$ 
naps at work all day and when he comes home he walks the floor all night and drinks." Well, the knee jerk reaction is to say, "I can straighten that out. I'll just get his day-night straightened out by giving him a sleeping pill." So what you do is you give him a sleeping pill at ten at night and he's in semi-coma all night and groggy and even more impaired the next day. So, assume that Valium ${ }^{\circledR}$, Librium ${ }^{\circledR}$, and Dalmane ${ }^{\circledR}$ all have their half-lives roughly doubled.

There is one benzodiazepine whose half-life is not doubled-Ativan ${ }^{\circledR}$. Ativan ${ }^{(}$'s half-life is the same in cirrhotics as it is in non-cirrhotics. But there's a catch. There's always a catch. In my experience Ativan ${ }^{\circledR}$ is a hallucinogen in about one out of twenty people who take it. But if I had to use a benzodiazepine in a cirrhotic, it would be either Ativan ${ }^{\circledR}$ in the normal dosages or Valium ${ }^{\circledast}$ in half normal dosages.

One of the reasons why drug half lives are doubled in cirrhotics is often overlooked: decreased kidney function. Most cirrhotics only have fifty per cent of normal kidney function. Even if their biochemical urine tests are normal, there still may be a decrease in kidney functioning. There are two reasons for this. One is that when your liver is shot you can't make urea, so your serum urea nitrogen level may actually be lower than normal. The other thing is, when you get malnourished, you don't have the same muscle mass. So, we say, "The urea nitrogen is normal and the creatinine is normal, so kidney functioning must be okay." That's fallacious.

Dr. Field: Years ago we used to utilize paraldehyde, but it's fallen into disuse, hasn't it?

Dr. Maddrey: Yes, it has. Paraldehyde is unpleasant to taste, if you aspirate it it'll do your lungs in, it smells pretty awful, and if you give it rectally it can cause a proctitis. There's a lot of problems with it. I don't think anyone uses it anymore. It's still not a bad drug. Older physicians who know how to use it may sometimes be safer using it instead of the new intravenous benzodiazepines.

That's about as much light as I can shed on this patient. I would be interested in the psychiatric viewpoint.

Bruce Blumenthal, M.S. in Clinical Psychology: Thank you, Dr. Maddrey. Dr. Shaw has outlined briefly Mr. J's history of involvement with our facility. He was first seen by psychiatry two years ago, when he received inpatient rehabilitation after being transferred from the medical service. Following discharge he was referred to the outpatient drug and alcohol clinic where he was placed in group and individual therapy, as well as being medicated with Desyrel $^{\odot}$.

The patient's psychosocial history is remarkable for being adopted at the age of three. Nothing is known about his life prior to the time he was adopted, including the nature and status of his biological parents. The patient himself remembers or chooses to remember very little about his childhood. He was the only child in the family. His mother was thirty-six at the time he was adopted; his father's age is not known. Mr. J attended parochial school, which he graduated from with second honors. His mother died when the patient was twenty-one, after which the patient's drinking increased remarkably. To this day he remembers this as a significant loss. His father died just prior to his initial contact with us two years ago.

Mr. J's alcohol problem began when he was thirteen. It began as a peer activity. 
At age eighteen he first learned that he was adopted. About this time he also began to become sexually involved with older men and began drinking more heavily. He became a bus boy after graduating from high school, a job he maintained until after the death of his mother, when his drinking intensified. He was married briefly at age twentyfour. He has one son, but the marriage only lasted a year and he has had no contact with his wife or his son since that time. Outside of that relationship, all of Mr. J's sexual experience has been homosexual. His work history is very spotty, chiefly because of his alcohol abuse. For the most part he has been a bus boy or a cook. He has also done delivery work.

When he was younger, Mr. J's homosexual relations were chiefly with older men. At the age of twenty-eight or twenty-nine a middle-life crisis seems to have set in and he began to seek out younger men around the age of eighteen or nineteen.

My involvement with Mr. J was as leader of a group of gay male substance abusers. In the beginning he was very eager to participate in the group. He was unlike the rest of the group, all of whom had at least one year of college education. Despite this, he was well integrated into and seemed accepted by the group. Indeed, he attended quite regularly and of the original members of the group was the one who maintained sobriety the longest.

While at times Mr. J seemed very much in tune with the group, at other times he would seem to fade away after having presented his issues. His communication with other group members was partially hindered by a hearing impairment. The other group members tried to be supportive and practical in their suggestions, attempting to help him with difficulties of daily living. Because of the composition of the group, there were times when we got into what I would say were more esoteric issues; at those times the patient seemed to be left behind. For the most part, however, the group attempted to support the patient in concrete ways.

The patient ascribed his drinking problem to the lack of a satisfying sexual relationship. If you ask Mr. J what he's looking for, he has quite a list. He's looking for a tall, blue-eyed, blond, eighteen to twenty year old gay male who doesn't drink or do drugs, and is employed full time so that he can share living expenses. Anything outside of his strict requirements is rejected. If he manages to meet someone who meets the other criteria, but drinks or does drugs, then it will be a short relationship. The other group members tried to help him with this, with little success.

Another issue with $\mathrm{Mr}$. $\mathrm{J}$ was that he would come up with a recitation of problems and have very good reasons why they were unsolvable.

At one point the patient needed a place to stay. The group helped the patient define the available resources. Moreover, they eventually took the patient to a gay roomate service, but the patient objected because of a very small fee. This is one example of how he defeated others' attempts to help him. He would provoke others into helping him solve his problems, then at the last minute sabotage their efforts in some way. This was infuriating.

Since coming to the clinic, the patient has dropped out of treatment, resumed drinking, been admitted to the hospital yet again, and readmitted into the outpatient clinic. Throughout this period the patient's issues have remained unchanged: he is not 
involved in the type of sexual relationship he wants and therefore he must drink. I last saw the patient approximately two months ago, at which time he was involved in relatively frequent episodes of binging. At that time he reported having had a relationship that is typical of this patient. On Sunday, Mr. J met someone. By Monday, they were talking about living together. On Tuesday, Mr. J bought the man an engagement ring. No more than two weeks later the relationship was over. The man who the patient originally felt met all his criteria was later discovered to be in his mid-thirties, an alcoholic, and having relations with men other than the patient.

Dr. Dorn: Could you speculate on this patient's dynamics?

Mr. Blumenthal: Yes. We know very little about this patient's family of origin. We do know that he was adopted at age three by a woman in her mid-thirties and a man who was probably about the same age. We can speculate that this couple had been trying to have children for a long time and decided to adopt a young toddler. Mr. J, who was entering the oedipal phase, was probably highly valued by his parents. Freud, in writing about Leonardo DiVinci's homosexuality, felt that a major factor was the sudden appearance of a father figure at age six. With our patient something similar happened at an earlier age. This may or may not have something to do with his homosexuality.

Mr. J's object choices, as we can see, are highly narcissistic. In fact there is narcissism coloring just about everything he does. He exhibits a lot of self-repudiation. If you saw him, you might not think of him as someone who cruises the homosexual part of town. Instead you might think of him as someone who seeks out homosexuals and beats them up. He is a very rough-looking character: short, dark skinned, has a bloated abdomen, and is missing most of his teeth. You might conceptualize him as the antithesis of the tall blond partner he seeks. This may be seen as an attempt to repudiate his own self-image and magically merge with the desired object.

Ms. Guerra may have other ideas that arose out of her individual therapy with the patient. Ms. Guerra?

Linda Guerra, M.A. in Counseling Psychology: During the first six months of therapy $\mathrm{Mr}$. J did relatively well. He never missed an appointment and appeared to maintain sobriety. In sessions the patient routinely had a litany of complaints about everything and everyone in his life. The theme of his complaints was: it's hopeless and people stink. He would make that statement about people who I knew had really gone out of their way to be helpful to the patient.

There was perhaps some magical thinking in that the few times the patient would talk about his mother he seemed to describe her almost as a madonna figure. There was an incredible feeling of longing for her. He said that on occasion after he'd downed a few fifths of vodka that he felt her presence in the room and that she was talking to him.

Unfortunately I have not seen Mr. J in some time, either. If he should return for treatment, he may need greater support than outpatient therapy provides. Dr. Serota, would you comment on this patient?

Ron Serota, M.D., Director, Inpatient Drug and Alcohol Services: The treatment modalities available for someone with the severity of Mr. J's disorder are severely 
limited. In our experience with him here, he has not been able to sustain what we attempted to offer him. It is difficult to see how he will be able to function outside of a residential community which has a fair degree of control over the patient's drug and alcohol intake. I think that you can't say at this point how much cognitive functioning the patient has lost because there have been times when he has been sober for several months and been able to relate in a meaningful way.

I think one of the issues that these patients raise that is apropos to consultation and liaison psychiatry is how we can help ourselves and each other deal with patients who are so frustrating, that is to say, patients who will not respond to our care. Typical responses are to feel rejected by or angry at the patient. I know we see this a lot in the general hospital in our drug and alcohol patients.

Dr. Gottheil, would you please comment on this case?

Ed Gottheil, M.D., Director, Drug and Alcohol Division, and Vice-Chairman of the Department of Psychiatry: This case presents many interesting questions for discussion. Somehow with alcoholism there has been this difficulty with accepting the disease concept. If it's a bad habit, then you ought to be able to stop doing it. Asking a patient to stop drinking is like asking a patient to stop being anxious or stop being depressed. It doesn't work.

One of the problems with this case is why it was so late in the game that he came to treatment. Where was this patient earlier on when perhaps we could have made more impact? It's almost surprising that at the point he was seen that he was able to develop a therapeutic relationship in individual and group therapy, and be helped to maintain abstinence for many months. I think it's a major achievement.

Certainly his liver disease is seen as terminal. They did an operative procedure and prolonged his life a bit, maybe a year or two. I don't know how outstanding that surgery was, but I do know helping him attain a period of sobriety was a great accomplishment, without which the surgery might conceivably have been quite useless.

We know that negative feelings towards alcoholics occurs in general hospital staff. Again, I think this harks back to the philosophical approach to this type of patient. When you go out of your way to help these patients and they don't take your advice, it's an affront. But we don't get that upset if someone comes back with another anxiety attack or psychotic episode. Again, I think this is because of the reluctance to view alcoholism as a disease entity instead of a bad habit.

If it is a disease and a chronic disease, then you count your accomplishments and come out pretty good, as much as anything else in psychiatry or medicine. There are not that many acute illnesses that have no residual problems.

I have trouble understanding the position of those who feel that alcoholics drink for pleasure. Here's a man whose drinking is pouching out his stomach, causing him irreparable physical, mental, and social harm. He is not drinking for pleasure! People who get depressed don't want to be depressed. It's difficult to see how one cannot conceptualize alcoholism as a disease when it's so self-destructive. Alcoholism in no way helps this patient achieve his goals.

The poor memory of alcoholics is certainly true. Undoubtedly at this point $\mathrm{Mr}$. $\mathrm{J}$ 
has significant cognitive impairment. Usually it's the new learning and memory that's lost, while verbalization and vocabulary is maintained. So, in conversation one might not pick up these patients' cognitive deficits, but they're there.

Any number of studies show that cognitive impairment from the time detox is begun lasts about three weeks. So, granted they may not remember what you say, but the attitude of the treating staff is important, and they may remember this. All is not memory impairment, however.

There is a strong genetic component to alcoholism. This is not $1: 1$. Not every alcoholic parent will have an alcoholic child. I think that one of the tasks of consultation and liaison psychiatry is to help frustrated medical staff learn that they are dealing with a disease, not a nasty person or someone who doesn't want to do what they're told. It's a magical word, disease. If someone's sick, then we can put up with all kinds of things we would otherwise not accept. If a schizophrenic patient is hostile and agitated, we can accept that because they're sick. If someone tends to be unappreciative and seemingly less crazy, we have problems with it.

Tied in with this is the question of outcome or the revolving door. You treat them and they come back; you treat them and they come back. Everyone feels sorry for people who have to deal with alcoholics. I don't. I think the results are as good as anywhere else. A lot depends on whether or not you approach alcoholism as an illness. If it's an illness you expect the same sort of results you get in other illnesses. If you're expecting complete and total cure forever more, you're going to be very sadly disappointed. But if you treat a depression and expect someone never to be depressed again, you're going to be equally disappointed. If you're talking about schizophrenics or people with busted up knees or anything else in medicine, you don't cure it forevermore.

If you establish reasonable criteria for improvement, and by improvement I don't mean spending six days in the gutter a week instead of seven, I mean significant improvement in their drinking, functioning, and lifestyle, then I think the treatment of alcoholics can be quite satisfying. Say the patient has an occassional bender. If you say that's a failure, I think your expectations are unreasonable. Only eight to ten per cent of patients will be totally abstinent at two years. If, however, you consider marked improvement as a criteria, then the statistics improve to fifty to sixty per cent. If you get them early, while the patient is still working, then you're in the eighty per cent range. In the emergency room setting, we're most likely to be referred patients like this who already have ascites. If they come in earlier in the course of their disease and have on a suit and a tie, staff frequently will not ask about their drinking history or refer these patients for treatment.

So, what can we do as consultation and liaison psychiatrists. First, I think we have to get across the idea that alcoholism is an illness. If you look as it as an illness, then you can expect reasonable results. Alcoholism is a very treatable illness if it's recognized early. The interesting thing is that the complications of alcoholism have always been seen as medical conditions. Alcohol withdrawal is clearly accepted as a medical illness requiring treatment, but the disease itself is not.

Dr. Field, would you comment on this patient? 
Dr. Howard Field: Yes, thank you. First of all, I can't remember this patient, so there are other ways to lose brain cells besides drinking.

There are, in the practice of medicine, that part of the physician's instinctive reaction to his patients having roots in his individual personality characteristics. We could spend several hours discussing them. There are few physicians who don't get angry with uncooperative patients. Physicians need patients to get well for their own sense of self-esteem. That's true in any illness, not just addictive disorders. I have a friend who says he can't treat three narcissistic patients in a row because he becomes exhausted, drained, and sick to his stomach after the third.

Secondly, we tend to look at addictive disorders in a judgemental, disapproving way. Sociologists study how we approach conditions. If the cause is considered to be willful misbehavior, then we tend to get angry at the patient. It would be marvelous if we could help our fellow medical physicians distance and protect themselves against the kind of injury that comes from treating this sort of patient.

Another issue is the question of how one deals with the patient who insists on doing things that are self-destructive. Such a patient raises social and ethical dilemmas. We do not have infinite money today for medical care. When I went into medicine, I was given the feeling that anything I could do to prolong the life of an individual was a contribution to the entire human race. This is no larger unquestioned. We are into an era of shifting ethical values, the so called "life boat" dilemma. Perhaps it would be best if we didn't treat this person and used our resources to treat a different kind of person, one who might benefit more from our help. On the other hand, we might not want to do heart transplants either. These are issues that as a whole we must decide. 